\title{
PENGARUH MODAL, TENAGA KERJA, BIAYA BAHAN BAKU DAN USIA TERHADAP PRODUKSI TIKAR DI KECAMATAN JANGKA KABUPATEN BIREUEN
}

\author{
Mulyanti ${ }^{*}$, Umaruddin Usman ${ }^{*}$ b \\ *Fakultas Ekonomi dan Bisnis Universitas Malikussaleh \\ a Corresponding author:mulyanti24041@gmail.com \\ b umaruddin@unimal.ac.id
}

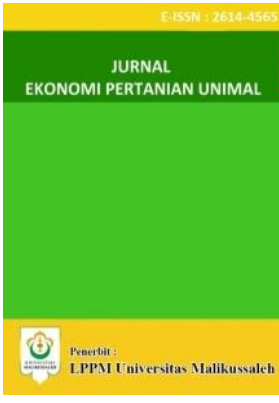

A R T I CLE I N F O RMA TION

A B S T R A C T

Keywords:

capital, labor, raw material costs, age and production
The purpose of this study is to see the effect of capital, labor, raw material costs and age on the production of Mats in the Jangka District of Bireuen Regency. The study uses primary data sourced from 54 respondents. This study employes multiple linear regression. The results of the studi showed that capital has a positive and significant effect on production, labor has a positive and significant effect on production, raw material costs has a positive and significant effect on production and age negatively effect on production but together with capital, labor, raw material costs and age variables have a positive effect on production.

\section{PENDAHULUAN}

Setiap industri yang didirikan akan menghasilkan output bagi industri tersebut. Output merupakan hasil produksi dalam suatu perusahaan. Semakin banyak output yang dihasilkan berarti berarti semakin besar pula perusahaan tersebut. Input dapat berpengaruh terhadap produksi suatu barang dan jasa. Jumah putput yang dihasilkan akan berpengaruh pada uang diawal, TK dan bahan utama untuk diperlukan. Semakin besar output (modal, TK serta input bahan baku) maka input bahan utama yang dibutuhkan juga semakin banyak.

Tingkat permintaan tikar tradisional berbahan dasar pandan, saat ini tidak lagi besar. Sejak ada tikar buatan pabrik dan karpet, tikar pandan sudah jarang diminati. Meskipun deminkian para pengrajin ini tetap akan bertahan menjalankan usahany. Selain untuk mempertahankan tradisi, produksi tikar pandan juga tetap harus dijalankan karena punya segmen pasar khusus. Untuk saat ini nilai jual tikar selalu cenderung mengalami penurunan. Harga untuk saat yang lalu sekitar Rp 65.000 sedangkan sekarang harganya Rp 50.000 untuk ukuran kecil.

Modal dalam proses pembuatan tikar merupakan biaya awal yang diperlukan, untuk modal saat ini dibeberapa usaha home industry memiliki maksimal Rp 300.000 untuk pembuaan tikar berbagai ukuran(Harjito, 2005)hubungan antara modal usaha dengan produksi berhubungan positif, dimana ketika produksi meningkat akan meningkatkan produksi pelaku industri.

Besarnya kapasitas produksi sangat dipengaruhi dari buruh yang bekerja saat ini besarnya angka buruh kerja yang diperlukan paling besar 2 jiwa karena usaha yang dilakukan masih bersifat home industry(Putong, 2009)menyatakan bahwa jumlah tenaga kerjaberdampak positif terhadap produksi jika TK kerjameningkat pasti akan semakin tinggi angka produksi.

Selain itu juga bahan baku adalah ha yang diutamakan didalam kegiatan industri untuk saat ini bahan baku daun dalam proses pembuatan tikar sudah sangat sulit diperoleh diwilayah kawasan daun pandan karenan untuk lahan daun pandan sudah banyak diambil alih untuk menanam tumbuhan lain yang dianggap lebih mengguntungkan (Swastha, 2000)menyatakan bahwa bahan baku bernampak positif terhadap produksi yang artinya apabila bahan baku meningkat maka akan meningkatkan pula jumlah produksi.

Dalam proses pembuatan tikar kalangan usia dipekerjakan karena usaha ini merupakan usaha turun temurun yang harus dikerjakan agar usaha ini tidak menghilangkan salah satu hasil budaya dahulu. (Swastha, 2000) menyatakan bahwa apabila usia meningkat maka akan menurunkan pula jumlah produksi. 
Peneliti ingin mengukur berapa banyak Kabupaten Bireuen mampu menghasilkan produksi tikar dalam perbulannya, karena dilihat dari keadaan yang ada bahwa untuk harga tikar sekarang yang diperjual belikan dipasar memiliki harga sangat rendah rendah, sehingga dengan tingginya harga ini apakah masyarakat yang dipekerjakan di produksi tikar ini pada Kabupaten Bireuen dapat mensejahterakan keluargnaya.

Berdasarkan observasi awal pada lokasi di penelitian ini sebagai berikut:

\section{Tabel 1}

Produksi, Modal, Tenaga Kerja dan Bahan Baku

\begin{tabular}{|c|c|c|c|c|}
\hline No & $\begin{array}{c}\text { Produksi } \\
\text { (Unit) }\end{array}$ & $\begin{array}{c}\text { Modal } \\
(\mathrm{Rp})\end{array}$ & $\begin{array}{c}\text { Tenaga } \\
\text { Kerja } \\
\text { (Jiwa) }\end{array}$ & $\begin{array}{c}\text { Biaya Bahan } \\
\text { Baku } \\
(\mathrm{Rp})\end{array}$ \\
\hline 1 & 1 & 20.000 & 2 & 200.000 \\
\hline 2 & 3 & 30.000 & 3 & 60.000 \\
\hline 3 & 1 & 50.000 & 1 & 80.000 \\
\hline 4 & 2 & 100.000 & 2 & 200.000 \\
\hline 5 & 2 & 80.000 & 1 & 150.000 \\
\hline
\end{tabular}

Sumber: Observasi Awal (2019)

Berdasarkan hasil observasi awal pada tabel diatas dapat dijelaskan bahwa berbeda-beda variabel modal, tenaga kerja dan bahan baku akan mempengaruhi produksi tikar, kita bisa melihat modal antara responden No 2 dengan responden No 5 punya modal yang berbeda, modal responden No 2 lebih kecil yaitu Rp 30.000 dibandingkan responden No 5 yaitu $\mathrm{Rp} 80.000$ namun produksi responden No 2 cukup tinggi dari responden No 5, dengan hal tersebut maka terjadilah permasalahan pada variabel modal yang berbeda dari teoriyang lain. Teori menyebutkan bahwa ketika modal meningkat maka akan meningkatkan jumlah produksi. Selanjutnya variabel tenaga kerja perbandingan antara responden No 1 dengan responden No 5 yang menyebutkan bahwa tenaga kerja responden No 1 lebih banyak yaitu 2 orang sedangkan responden No 5 hanya 1 orang, namun jumlah produksi responden No 5 lebih besar dibandingkan responden No. 1, karenanya terjadilah permasalahan pada variabel tersebut yang tidak sesuai teori, didalam teori menyebutkan banyaknya tenaga kerja dalam suatu industri maka akan meningkatkan jumlah produksi. Sedangkan terakhir permasalahan pada variabel anggrana bahan utama perbandingan antara responden No. 1 dan responden No. 2 bahwa anggrana bahan utama responden No. 1 lebih besar yaitu Rp 200.000, sedangkan responden No. 2 Rp 60.000, namun produksi responden No. 2 cukup besar dari responden No. 1, sehingga terjadilah permasalahan pada variabel tersebut yang tidak sesuai dengan teori, teori menyebutkan bahwa semakin besar bahan baku yang dikeluarkan maka akan meningkatkan jumlah produksi dalam suatu industri.

Tujuannya untuk melihat pengaruh modal, tenaga kerja, biaya bahan baku dan usia terhadap produksi Tikar di di Kecamatan Jangka Kabupaten Bireuen.

\section{KAJIAN TEORITIS}

\section{Produksi}

Produksi ialah proses produksi dari bahan mentah menjadi bahan produksi sehingga mempunyai memiliki nilai tambah(Sukirno, 2006).

Produksi merupakan pekerjaan barang input menjadi brang output. Kegiatan yang dimaksud tersebut disebut kegiatan produksi (Sugiarto, 2015).

Berdasarkan kesimpulan pakar diatas maka dapat disimpulkan produksi merupakan kegiatan menciptakan atau menghasilkan suatu barang akan ada harga tertentu yang didalamnya terdapat input ataupun output.

\section{Modal}

Modal adalah barang yang diproduksi oleh sistem ekonomi yang digunakan sebagai input untuk memperoduksi barang dan jasa (Fair, 2007).

Modal juga bisa dilakukan dengan investasi(Sukirno, 2006).

Modal usaha menurut (Ardi, 2011)adalah pengeluaran awal untuk proses berjualan guna memperoleh keuntungan.

Dari beberapa pengertian modal diatas maka disimpulkan bahwa modal digunakan untuk membeli barang dagangan, pembiayaan upah dan pembiayaan operasional lainnya yang berlangsung terus-menerus dalam kegiatan jual beli yang diharapkan akan meningkatkan pendapatan.

Hubungan antara variabel modal memiliki hubungan positif terhadap produksi, dimana ketika modal besar, maka akan meningkatkan produksi (Sermy, 2015)dimana ketika modal pembelian untuk bahan-bahan pembuatan tikar akan semakin banyak, dan akan mampu meningkatkan produksi tikar.

\section{Tenaga Kerja}

Tenaga kerja merupakan manusia berada pada usia kerja dan mampu bekerja baik di dalam maupun di luar hubungan kerja (Putong, 2009).

Sedangkan pendapat (Rosyidi, 2014)bahwa tenaga kerja merujuk pada kemampuan manusiawi yang dapat disumbangkan untuk memungkinkan dilakukannya produksi barang-barang dan jasajasa. 
Berdasarkan pakar tersebut diambil kesimpulan bahwa TK adalah seseorang yang pada usia kerja sudah mampu bekerja untuk menciptakan produk guna memnuhi kebutuhan dirinya dan keluarganya.

Hubungan antara variabel tenaga kerja memiliki hubungan positif terhadap produksi(Sermy, 2015)dimana ketika tenaga kerja semakin banyak, maka akan meningkatkan produksi, karena besarnya jumlah tenaga kerja akan mendorong produksi semakin banyak.

\section{Biaya Bahan Baku}

Biaya bahan baku merupakan pengeluaranpengeluaran atau nilai pengorbanan untuk memperoleh barang atau jasa yang berguna untuk masa yang akan datang(Sukirno, 2004).

Menurut (Mulyadi, 2008)biaya bahan baku adalah pengorbanan sumber ekonomi, yang diukur dalam bentuk duit, yang telah terjadi atau yang kemungkinan akan terjadi untuk tujuan tertentu.

Berdasarkan pakar tersebut diambil kesimpulan bahwa biaya bahan baku merupakan pengeluaran-pengeluaran atau nilai pengorbanan untuk memperoleh bahan baku untuk proses produksi kedepannya bahan utama atau bahan dasara yang dilakukan,

Hubungan antara variabel anggaran bahan utama memiliki hubungan positif terhadap produksi (Akbar, 2017)semakin banyak anggaran bahan utama yang ada maka akan dapat memproduksi tikar lebih banyak sehingga akan meningkatkan jumlah produksi tikar.

\section{Usia}

Penduduk dalam kelompokumur 15-55 tahun, terutama laki-laki umumnya dituntut untuk mencarinafkah. Lebih lanjut penduduk di atas 55 tahun sudah mulai menurunkemampuannya untuk bekerja (Ardi, 2011).

Usia merupakan waktu hidup atau ada (sejak dilahirkan atau diadakan) (Fair, 2007).

Berdasarkan para pakar tersebut diambil kesimpulan bahwa usia merupakan lamanya masa kehidupan seseorang untuk menjalani rutinas sehari-hari.

Hubungan antara variabel usia memiliki hubungan negatif terhadap produksi (Akbar, 2017)semakin tinggi usia seseorang yang ada maka akan dapat mengurangi proses produksi tikar sehingga akan mengurangi jumlah produksi tikar.

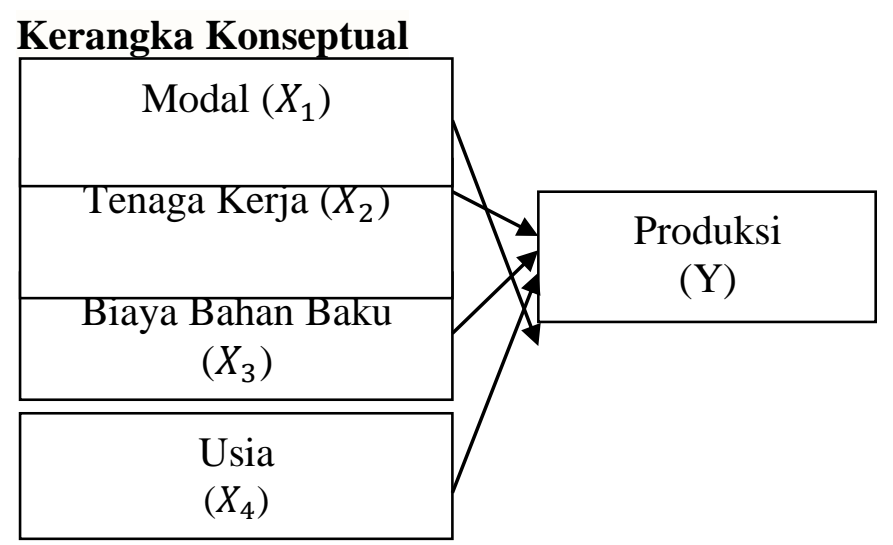

\section{Hipotesis}

Berdasarkan kerangka konseptual diatas maka dalam dilakukan hipotesis sebagai berikut:

$H_{1}$ : Diduga modal berpengaruh terhadap Produksi Tikar di di Kecamatan Jangka Kabupaten Bireuen

$\mathrm{H}_{2}$ : Diduga tenaga kerja berpengaruh terhadap Produksi Tikar di di Kecamatan Jangka Kabupaten Bireuen

$H_{3}$ : Diduga biaya bahan baku berpengaruh terhadap Produksi Tikar di di Kecamatan Jangka Kabupaten Bireuen

$H_{4}$ : Diduga usia berpengaruh terhadap Produksi Tikar di di Kecamatan Jangka Kabupaten Bireuen

\section{METODE PENELITIAN}

\section{Populasi}

Dalam penelitian ini jumlah populasi yang diambil adalah jumlah seluruh pemilik yang telah mendirikan usaha home industri tikar tersebut, berjumlah 54 pengrajin di di Kecamatan Jangka Kabupaten Bireuen.

\section{Sampel}

Sampel yag digunakan metode sensus dikarenakan jumlah populasinya tidak terlalu banyak atau terjangkau untuk saya teliti semua dalam jangka waktu yang tidak terlalu lama untuk penelitian inisehingga sampel yang digunakan pada penelitian ini sebanyak54 pengrajin berdasarkan populasi yang disebutkan sebelumnya.

\section{Definisi Operasional Variabel}


1. $\operatorname{Modal}\left(X_{1}\right)$ : jumlah uang yang dikeluarkan pada proses awal berdirinya industri. Diukur dengan satuan rupiah.

2. Tenaga Kerja $\left(X_{2}\right)$ : orang yang berada pada usia kerja dan mampu bekerja baik. Diukur dengan satuan jiwa.

3. Biaya Bahan Baku $\left(X_{3}\right)$ : biaya yang dikeluarkan untuk proses awal dibuatnya barang industri. Diukur dengan satuan Rupiah.

4. Usia $\left(X_{4}\right)$ : lamanya masa kehidupan seseorang untuk menjalani rutinitas seharihari. Diukur dengan satuan tahun

5. Produksi $(Y)$ : suatu proses mengubah input menjadi output,sehingga memliki nilai tambah. Diukur dengan satuan unit.

\section{Metode Analisis data}

Untuk memecahkan masalah pada penelitian ini maka penulis melakukan analisis data dengan memakai metode kuantitatif dengan menggunakan programEviews versi 10 yang berupa metode Regresi Linier Berganda (RLB) sebagai berikut:

$$
Y=\beta_{0}+\beta_{1} \operatorname{Ln} X_{1}+\beta_{2} \operatorname{LnX} X_{2}+\beta_{3} \operatorname{LnX} X_{3}
$$$$
+\beta_{4} X_{4}+e i
$$

Keterangan:

$\begin{array}{ll}\boldsymbol{Y} & =\text { Produksi } \\ \boldsymbol{\beta}_{\mathbf{0}} & =\text { Konstanta } \\ \boldsymbol{\beta}_{\mathbf{1}} \boldsymbol{\beta}_{\mathbf{2}} \boldsymbol{\beta}_{\mathbf{3}} & =\text { Koefisien Regresi } \\ \boldsymbol{L n X}_{\mathbf{1}} & =\text { Modal } \\ \boldsymbol{L n X}_{2} & =\text { Tenaga Kerja } \\ \boldsymbol{L n} \boldsymbol{X}_{3} & =\text { BiayaBahan Baku } \\ \boldsymbol{X}_{\mathbf{4}} & =\text { Usia } \\ \boldsymbol{e i} & =\text { Error Term }\end{array}$

\section{Uji Normalitas}

Uji normalitas dilakukan untuk melihat apakah data terdistribusi secara normal atau tidak Pengujian normalitas dapat dilakukan dengan menggunakan metode Jarque-Bera (J-B) (Widarjono, 2013).

Jika nilai probability dari statistik J-B lebih besar dari taraf kepercayaan 5\% $(0,05)$ berarti bahwa residul data berdistribusi normal. Sebaliknya jika nilai probability dari statistik J-B lebih kecil dari taraf kepercayaan 5\% $(0,05)$ berarti bahwa residul data tidak berdistribusi normal(Widarjono, 2013).

\section{Uji Asumsi Klasik}

Adapun uji asumsi klasik yang digunakan dalam penelitian ini adalah sebagai berikut:

\section{Uji Heteroskedastisitas}

Uji heteroskedastisitas dilakukan untuk melihat kesamaan variance pada data yang diperoleh(Ghozali, 2010).

Metode pengujian yang lain dapat digunakan adalah metode White dasar Pengambilan keputusan, jika nilai probabilitas dari Obs $* R$-Squared $>X^{2}$ tabel, maka ada indikasi terjadi heteroskedastisitas; jika nilai probabilitas dari $O b s^{*} R$-Squared $<X^{2}$ tabel, maka model tersebut terbebas dari heteroskedastisitas.

\section{Uji Multikolinearitas}

Multikolinieritas dilakukan untuk melihat apakah ada terjadi hubungan antar variabel bebas. Jika koefisien korelasi antara masing-masing variabel bebas lebih besar dari 0.8 berarti terjadi multikolinieritas begitu juga sebaliknya.Mulktikolinearitas dalam penelitian ini diuji dengan melihat nilai correlation matrix yang diuji dari covariance analysis.

\section{Pengujian Hipotesis}

Uji t

Uji $\mathrm{t}$ dilakukan untuk melihat apakah variable bebas memiliki hubungan terhadap variabel terikat(Subri, 2013). Adapun kriteria pengujiannya adalah sebagai berikut:

1. Jika $t_{\text {hitung }}>t_{\text {tabel }}$ Ho ditolak dan menerima Ha yang artinya variabel bebas (X) secara parsial mempengaruhi variabel terikat (Y).

2. 2. Jika $t_{\text {hiutng }}<t_{\text {tabel }}$ maka Ho diterima dan menolak Ha yang artinya variabel bebas (X) secara parsial tidak mempengaruhi vaiabel terikat (Y).

\section{Uji F}

Uji $\mathrm{F}$ digunakan untuk melihat hubungan variabel bebas terhadap terikat secara simultan.

1. Jika $F_{\text {hitung }}>F_{\text {tabel }}$ Ho ditolak dan menerima Ha yang artinya secara simultan variabel bebas (X) mempengaruhi variabel terikat (Y).

2. Jika $F_{\text {hiutng }}<t_{\text {Fabel }}$ maka Ho diterima dan menolak Ha yang artinya secara simultanvariabel bebas (X) tidak mempengaruhi vaiabel terikat (Y).

\section{Koefisien Korelasi (R)}

Menurut (Sugiyono, 2015)Koefisien korelasi adalah sebuah angka yang dapat dijadikan petunjuk untuk mengetahui seberapa besar 
kekuatan korelasi di antara variabel yang sedang diselidiki korelasinya.

Pedoman untuk memberikan interpretasi koefisien sebagai berikut:

- $>0,00-0,199=$ sangat rendah

- $>0,20-0,399=$ rendah

- $>0,40-0,599=$ sedang

- $>0,60-0,799=$ kuat

- $>0,80-0,99=$ sangat kuat

- $>1=$ korelasi sempurna

\section{Koefisien Determinasi $\left(R^{2}\right)$}

Koefisien determinasi $\left(R^{2}\right)$ adalah satu ukuran yang digunakan untuk mengukur pengaruh variabel independen terhadap variansi dependen, dengan $0<R^{2}<1$. Koefisien determinasi pada regresi linier sering diartikan sebagai seberapa besar kemampuan semua variabel bebas dalam menjelaskan varians dari variabel terikatnya. Secara sederhana koefisien determinasi dihitung dengan mengkuadratkan Koefisien Korelasi (R)(Subri, 2013).

\section{HASIL PENELITIAN DAN PEMBAHASAN}

\section{Hasil Regresi Linier Berganda}

\section{Tabel}

\section{Hasil Analisis Regresi Linear Berganda} Dependent Variable: LOG(PRODUKSI)

\begin{tabular}{crrr}
\hline \hline Variable & Coefficient & t-Statistic & Prob. \\
\hline \hline C & -8.291754 & -6.187102 & 0.0000 \\
LOG(MODAL) & 0.325518 & 3.780981 & 0.0004 \\
LOG(TENAGA_KERJA) & 0.351117 & 4.836235 & 0.0000 \\
LOG(BAHAN_BAKU) & 0.388924 & 3.887029 & 0.0003 \\
USIA & -0.011164 & -2.743295 & 0.0085 \\
\hline \hline
\end{tabular}

\begin{tabular}{lll}
\hline \hline R-squared & 0.660373 & F-statistic \\
Adjusted R-squared & 0.632648 & Prob(F-statistic) \\
& & Durbin-Watson stat \\
\hline
\end{tabular}

Sumber: Hasil Penelitian, 2019 (data diolah)

$$
\begin{gathered}
\mathrm{Y}=-\mathrm{-8.2917}+0.3255 \operatorname{Ln} X_{1}+0.3511 \operatorname{Ln} X_{2}+ \\
0.3889 \operatorname{Ln} X_{3}-0.0111 X_{4}
\end{gathered}
$$

Nilai konstanta sebesar -8.2917 artinya jika variabel modal, tenaga kerja, bahan baku dan usia dianggap konstan, maka variabel produksi juga akan konstan sebesar -8.2917 unit.

Nilai koefisien regresi modalsebesar 0.3255menunjukkan hubungan positifyang memberi arti jika variabel modal meningkat sebesar $1 \%$ maka akan meningkatkan variabel produksi sebesar $0.3255 \%$ dengan asumsi bahwa variabel tenaga kerja, bahan baku dan usia dianggap tetap.
Nilai koefisien tenaga kerja sebesar 0.3511menunjukkan hubungan positifyang memberi arti bahwa jika variabel tenaga kerja meningkat sebesar 1 jiwa maka akan meningkatkan variabel produksi sebesar $0.3511 \%$ dengan asumsi bahwa variabel modal, bahan baku dan usia dianggap tetap.

Nilai koefisien bahan baku sebesar 0.3889 menunjukkan hubungan positif yang memberi arti bahwa jika variabel bahan baku meningkat sebesar $1 \%$ maka akan meningkatkan variabel produksi sebesar $0.3889 \%$ dengan dengan asumsi variabel modal, tenaga kerja dan usia dianggap tetap.

Nilai koefisien usia sebesar -0.0111 menunjukkan hubungan negatif yang memberi arti bahwa jika variabel usia meningkat sebesar 1 tahun maka akan menurunkan variabel produksi sebesar $0.0111 \%$ dengan dengan asumsi variabel modal, tenaga kerja dan bahan baku dianggap tetap.

\section{Hasil Normalitas}

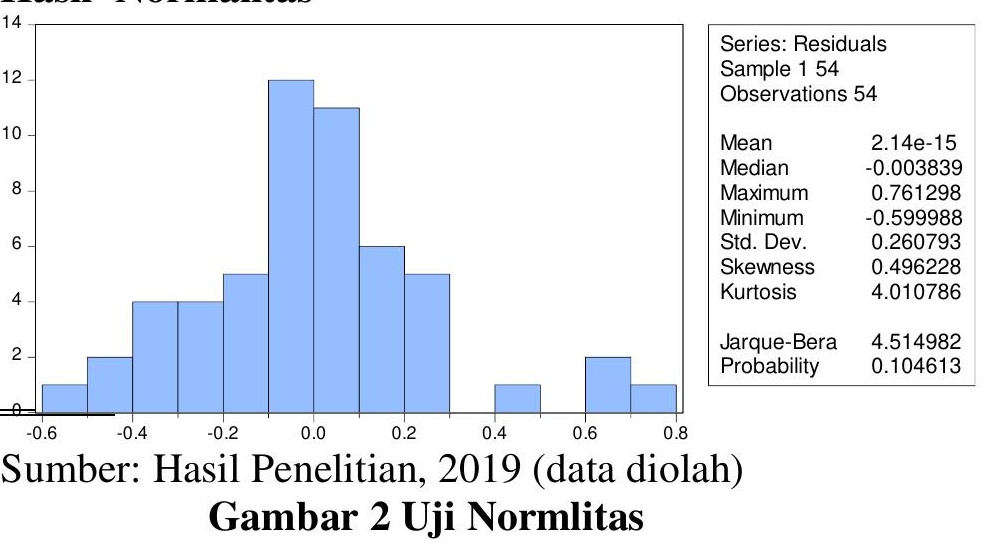

Nilai $X^{2}$ tabel dengan $\operatorname{df}(4)=9,48$. Jika dibandingkan dengan nilai J-B pada tabel diatas sehesar 4,51<9,48, maka dapat disimpulkan bahwa 26.8degb regresi, variabel penggangu atau residual dadaono model sudah terdistribusi dengan normal. Häpq5? juga bisa dilihat dari probabilitas (P-value) sebesar $0,10>0,05$.

\section{Hasil Uji Asumsi Klasik \\ Hasil Uji Heteroskedastisitas}

\section{Tabel}

\section{Uji Heteroskedastisitas}

Heteroskedasticity Test: White

\begin{tabular}{llll}
\hline \hline F-statistic & 1.419459 & Prob. F(4,49) & 0.2415 \\
Obs*R-squared & 5.607449 & Prob. Chi-Square(4) & 0.2304 \\
Scaled explained SS & 6.950562 & Prob. Chi-Square(4) & 0.1385 \\
\hline \hline
\end{tabular}

Sumber: Hasil Penelitian, 2019 (data diolah)

Berdasarkan Tabel diatas menunjukkan bahwa data model yang digunakan dalam 
penelitian ini terbebas dari heteroskedastisitas, dari hasil tersebut dilihat dari obs $* R$-Squared $<X^{2}$ tabel pada $\operatorname{df}(4)=9,48$ sehingga $5,60<9,48$. Hal ini juga bisa dilihat dari nilai probability (P-value) sebesar $0,23>0,05$.

\section{Hasil Uji Multikolonearitas}

Tabel

Uji Multikolonearitas

\begin{tabular}{|c|c|c|c|c|}
\hline & Modal & $\begin{array}{c}\text { Tenaga_ } \\
\text { Kerja }\end{array}$ & $\begin{array}{c}\text { Bahan_- } \\
\text { Baku }\end{array}$ & Usia \\
\hline Modal & 1 & 0.1173 & 0.2014 & 0.0970 \\
\hline Tenaga_Kerja & 0.1173 & 1 & 0.3095 & 0.0369 \\
\hline Bahan_Baku & 0.2014 & 0.3095 & 1 & 0.0419 \\
\hline Usia & 0.0970 & 0.0369 & 0.0419 & 1 \\
\hline
\end{tabular}

Sumber: Hasil Penelitian, 2019 (data diolah)

Berdasarkan Tabel diatas, diketahui bahwa nilai correlation matrixantar variabel bebas tidak melebihi 0,8, maka dapat dikatakan pada penelitian ini tidak terjadinya multikolinieritas pada empat variabel bebas ini.

\section{Pengujian Hipotesis}

\section{Uji t}

Tabel Uji t

\begin{tabular}{|l|l|l|l|l|}
\hline \multicolumn{5}{|c|}{ Variabel Dependen (Pengeluaran pemerintah) } \\
\hline $\begin{array}{l}\text { Varibael } \\
\text { Independen }\end{array}$ & $\begin{array}{l}\text { T- } \\
\text { Statistik }\end{array}$ & Prob & Keterangan & Hipotesis \\
\hline Modal & 3.780 & 0,0004 & Signifikan & Diterima \\
\hline Tenaga Kerja & 4.836 & 0,0000 & Signifikan & Diterima \\
\hline $\begin{array}{l}\text { Biaya Bahan } \\
\text { Baku }\end{array}$ & 3.887 & 0,0003 & Signifikan & Diterima \\
\hline Usia & -2.743 & 0,0085 & Signifikan & Diterima \\
\hline
\end{tabular}

Sumber: Hasil Penelitian,2019 (data diolah)

Dari Tabel 5 di atas dapat dilihat bahwa nilai $t_{\text {hitung }}$ dari modaladalah sebesar 3,7809 dengan nilai signifikannya adalah 0,0004, sementara nilai $t_{\text {tabel }}$ dengan $(\mathrm{df})=\mathrm{n}-\mathrm{k}(54-5=$ 49) diperoleh nilai sebesar 2,67artinya kecil dari derajat kesalahan sebesar $1 \% \quad(0,01)$. Maka keputusannya menolak $H_{0}$ dan menerima $H_{1}$, yang berarti secara parsial modal berpengaruh positif terhadap produksi tikar di Kecamatan Jangka Kabupaten Bireuen.

Selanjutnya nilai $t_{\text {hitung }}$ dari tenaga kerjaadalah sebesar 4,8362 dengan nilai signifikannya adalah 0,0000 , sedangkan nilai $\mathrm{t}_{\text {tabel }}$ sebesar 2,67 artinya lebih kecil dari derajat kesalahan sebesar 1\% (0,01). Maka keputusannya menolak $\mathrm{H}_{0}$ dan menerima $\mathrm{H}_{2}$, yang berarti secara parsial tenaga kerja berpengaruh positif terhadap produksi tikar di Kecamatan Jangka Kabupaten Bireuen.

Kemudian variabel nilai $t_{\text {hitung }}$ dari bahan bakuadalah sebesar 3.8870 dengan nilai signifikannya adalah 0,0003 , sedangkan nilai $t_{\text {tabel }}$ sebesar 2,67artinya lebih kecil dari derajat kesalahan sebesar $1 \%(0,01)$. Maka keputusannya menolak $H_{0}$ dan menerima $H_{3}$, yang berarti secara parsial bahan bakuberpengaruh positif terhadap terhadap produksi tikar di Kecamatan Jangka Kabupaten Bireuen.

Kemudian yang terakhir variabel nilai $t_{\text {hitung dari usiaadalah sebesar 2,7432 dengan nilai }}$ signifikannya adalah 0,0085 , sedangkan nilai $t_{\text {tabel }}$ sebesar 2,67artinya lebih kecil dari derajat kesalahan sebesar $1 \%(0,01)$. Maka keputusannya menolak $H_{0}$ dan menerima $H_{4}$, yang berarti secara parsial usiaberpengaruh positif terhadap terhadap produksi tikar di Kecamatan Jangka Kabupaten Bireuen

\section{Uji F}

Hasil uji F dapat dilihat pada tabel berikut: Tabel Uji F

\begin{tabular}{|l|l|l|l|l|}
\hline F-Statistik & T-tabel & Prob & Keterangan & Hipotesis \\
\hline 23.8189 & 4,20 & 0,000000 & Signifikan & Diterima \\
\hline
\end{tabular}

Sumber: Hasil Penelitian, 2019 (data diolah)

Dari Tabel 6 di atas dapat diketahui bahwa

nilai $F_{\text {hitung }}$ sebesar23.8189 dengan nilai signifikansebesar 0,00000 pada taraf kepercayaan $99 \%$. Sedangkan $F_{\text {tabel }}$ diperoleh nilai sebesar 4,20 pada $\alpha=0,01$. Dengan demikian $F_{\text {hitung }}>F_{\text {tabel }}$ yaitu $29,27>4,21$ dan nilai signifikan sebesar $0,000<0,01$. Dari hasil uji F ini berarti $H_{a}$ diterima atau menolak $H_{0}$, dengan demikian secara bersama-sama modal, tenaga kerja, bahan baku dan usia berpengaruh positif terhadap produksi tikar di Kecamatan Jangka Kabupaten Bireuen.

\section{Koefisien Korelasi (R)}

Nilai koefisien korelasi adalah $R=\sqrt{R^{2}}=$ $\sqrt{0,6604}=0,8934(89,34 \%)$ yang menunjukkan bahwa hubungan antara variabel modal, tenaga kerja, bahan baku dan usia terhadap produksi memiliki hubungan yang sangat kuat secara positif karena nilai korelasi 0,7982 mendekati nilaipositif satu $(+1)$.

\section{Koefisien Determinasi $\left(\boldsymbol{R}^{\mathbf{2}}\right)$}

Nilai koefisien determinasi $\left(R^{2}\right)$ sebesar 0,6326yang artinya bahwa ada kaitan antara variabel bebas dan variabel terikat, perubahan yang terjadi pada variabel terikat dapat dijelaskan oleh variabel bebas sebesar 0,6326 $(63,26 \%)$, sedangkan yang dipengaruhi oleh variabel lain diluar model ini adalah sebesar 1-0,6326=0,3674 $(36,74 \%)$. 


\section{Pembahasan \\ Pengaruh Modal Terhadap Produksi}

Berdasarkan hasil analisis data ditemukan bahwa variabel modal $\left(X_{1}\right)$ berpengaruh secara positif terhadap produksi (Y) dengan nilai signifikan $\alpha=1 \%$. Hal ini bermakna bahwa tingginya modal $\left(X_{1}\right)$, maka akan meningkatkan produksi tikar di Kecamatan Jangka Kabupaten Bireuen.

Hasil penelitian ini sejalan dengan penelitian yang dilakukan oleh (Dd, 2016)di Kabupaten Manado bahwa variabel modal kerjaberpengaruh signifikan terhadap produksi industri kecil olahan ikan di Kota Manado, iniberarti Ha diterima.

Hasil penelitian sesuai dengan penelitian yang pernah dilakukan(Akbar, 2017)di Kota Pekanbaru menunjukkan bahwa modal berpengaruh secara positif signifikan terhadap komitmen jumlah produksi. Artinya, saat jumlah modal yang digunakan naik maka produksi yang dihasilkan juga akan meningkat.

\section{Pengaruh Tenaga KerjaTerhadap Produksi}

Berdasarkan hasil analisis data ditemukan bahwa tenaga kerja $\left(X_{2}\right)$ berpengaruh terhadap variabel produksi (Y) dan signifikan sebesar $\alpha=$ $1 \%$. Hal ini bermakna bahwa jika tenaga kerja $\left(X_{2}\right)$ meningkat maka akanmeningkatkan produksi tikar di Kecamatan Jangka Kabupaten Bireuen.

Hasil penelitian ini sejalan dengan penelitian yang pernah dilakukan oleh (Dd, 2016)di Kabupaten Manadobahwa variabel tenaga kerjaberpengaruh signifikan terhadap produksi industri kecil olahan ikan di Kota Manado, iniberarti Ha diterima.

Hasil penelitian ini sejalan dengan penelitian yang pernah dilakukan oleh (Sermy, 2015)di Kabupaten Pekanbarubahwa variabel tenaga kerja berpengaruh positif terhadap produksi industri furnitur dari alumunium di Kota Pekanbaru. Yang artinya saat jumlah tenaga kerja yang digunakan dalam industri tersebut naik, maka produksi furnitur dari alumunium juga akan mengalami peningkatan.

\section{Pengaruh Biaya Bahan Baku Terhadap Produksi}

Berdasarkan hasil analisis data ditemukan bahwa variabel bahan baku $\left(X_{3}\right)$ berpengaruh terhadap variabel produksi (Y) dan signifikan pada $\alpha=1 \%$. Hal ini bermakna bahwa bahan baku $\left(X_{3}\right)$ meningkat maka akan meningkatkanproduksi tikar di Kecamatan Jangka Kabupaten Bireuen.

\section{Pengaruh Usia Terhadap Produksi}

Berdasarkan hasil analisis data ditemukan bahwa variabel usia $\left(X_{1}\right)$ berpengaruh secara negatif terhadap produksi (Y) dengan nilai signifikan $\alpha=1 \%$. Hal ini bermakna bahwa tingginya usia $\left(X_{1}\right)$, maka akan menurunkan produksi tikar di Kecamatan Jangka Kabupaten Bireuen.

Hasil penelitian ini sejalan dengan penelitian yang dilakukan oleh (Dd, 2016)di Kabupaten Manado bahwa usia berpengaruh signifikan terhadap produksi industri kecil olahan ikan di Kota Manado, ini berarti Ha diterima.

Hasil penelitian sesuai dengan penelitian yang pernah dilakukan(Akbar, 2017)di Kota Pekanbaru bahwa usia berpengaruh secara negatif signifikan terhadap komitmen jumlah produksi. Artinya, ketika usia seorang pekerja meningkat, maka akan mengurangi jumlah produksi dalam bekerja, karena ketika seseorang berlanjut usia akan mengalami kondisi yang lemah, dengan lemahnya kondisi seseoraang akan mengurangi kualitas dan kuantitas dalam bekerja, sehingga produktivitas seorang pekerja akan mengalami penurunan.

\section{PENUTUP}

\section{Kesimpulan}

1. Hasil yang ditemukan variabel modal, tenaga kerja dan bahan baku berpengaruh positif terhadap produksi. Adanya pengaruh ini memperjelaskan seiring dengan terjadinya peningkatan modal, tenaga kerja dan bahan baku, maka produksi juga akan meningkat.

2. Hasil yang ditemukan variabel usia berpengaruh negatif terhadap produksi. Adanya pengaruh ini meperlihatkan bahwa seiring dengan terjadinya peningkatan usia, maka produksi juga akan menurun.

3. Secara bersama-sama variabel modal, tenaga kerja, bahan bakudan usia berpengaruh positif terhadap produksi, dan besarnya pengaruh modal, tenaga kerja, bahan baku dan usia terhadap produksi adalah sebesar $63,26 \%$ dan sisanya sebesar $(1-63,26 \%)=$ $36,74 \%$ dapat dijelaskan diluar model penelitian ini. 


\section{Saran}

Adapun beberapa saran-saran yang diharapkan penulis dalam penelitian ini adalah sebagai berikut:

1. Tingginya modal akan meningkatkan produksi, karena modal tinggi maka bahan baku yang tersedia semakin banyak dengan banyaknya bahan baku akan menghasilkan produksi yang banyak pula.

2. Semakin banyak tenaga kerja akan meningkatkan produksi, dikarenakan tenaga kerja akan membantu proses meningkatkan jumlah produksi dapat dihitung ketika satu jiwa menghasilkan 1 unit tikar perhari maka apabila tenaga kerja leb ih dari satu maka akan menghasilkan jumlah tikar yang banyak tiap harinya.

3. Mengintensikan kembali bahwa kerajinan tikar di Kecamatan jangka Kabupaten Bireuen bahwa bireuen memiliki potensi yang sangat baik dan menguntungkan baik bagi pendapatan masyarakat dan pendapatan daerah tersebut, maka kerajinan tikar tersebut harus dapat terus dikembangkan.

4. Diharapkan kepada Pemerintah setempat agar mensosialisasikan pentingnya menbuka usaha yang akan memperkerjakan masyarakat untuk membantu pertumbuhan perekonomia mereka.

5. Perlu adanya penelitian lanjutan, sehingga diperoleh temuan yang lebih bervariasi dan lebih baik dalam menjelaskan permintaan dengan metode penelitian yang berbeda.

\section{DAFTAR PUSTAKA}

Akbar, Y. R. (2017). Analisis Faktor - Faktor Yang Mempengaruhi Produksi Industri Furniture Kaca Dan Alumunium Di Kota Pekanbaru. Jom FEKON, Vol. 4(No.1).

Ardi, N. L. (2011). Pengantar Kebutuhan Dasar Manusia. Jakarta: Salemba Mitra Wacana.

Bonanta, H. (2015). Faktor-Faktor Yang Mempengaruhi Produksi Industri Makanan Di Propinsi Riau. Journal Of Economyc, Vol 3(No 1).

D, A. P. dan S. (2002). Koperasi, Kewirausahaan dan Usaha Kecil. Jakarta: Rineka Cipta.

Dd, S. (2016). Analisis Faktor-Faktor Yang Mempengaruhi Produksi Industri Kecil Olahan Ikan Di Kota Manado. Jurnal Ilmiah, Vol 3(No 2).

Fair, C. \&. (2007). Prinsip-Prinsip Ekonomi
Mikro. (Y. Andri Zaimur. Terjemahan).

Jakarta: Erlangga.

Ghozali, I. (2010). Aplikasi Analisis Multivariate dengan Program SPSS Edisi I. Bogor: Universitas Dipenogoro.

Harjito, M. dan A. (2005). Manajemen Keuangan. Yogyakarta: Ekonisia.

Mulyadi, S. (2008). Ekonomi Sumber Daya Manusia Dalam Perspektif Pembangunan. Jakarta: Rajawali Press.

Nur, H. M. (2013). Pengaruh Modal Dan Tenaga Kerja Usaha Pengrajin Batik Tulis Klasik Terhadap Tingkat Produksi (Studi Pada Industri Kecil Menengah “ Ikm “ Batik Tulis Klasik Di Desa Margorejo, Kecamatan Kerek, Kabupaten Tuban). Jurnal Jejak, Vo 3(No 2).

Putong, I. (2009). Economics: Pengantar Mikro dan Makro, Edisi Ketiga. Jakarta: Salemba Media.

Rosyidi. (2014). Pengantar Teori Ekonomi. Jakarta: Rineka Cipta.

Sermy, M. (2015). Analisis Faktor-Faktor Yang Mempengaruhi Produksi Industri Furnitur Dari Alumunium Di Kota Pekanbaru. Jom FEKON, Vol 2(No. 2).

Subri. (2013). Ekonomi Sumber Daya Manusia. (P. R. G. Persada, Ed.). Jakarta.

Sugiarto. (2015). Ekonomi Mikro. Jakarta: Gramedia Pustaka.

Sugiyono. (2015). Statistik Untuk Penelitian. Bandung: Alfabeta.

Sukirno, S. (2004). Pengantar Teori Makro. Jakarta: PT. Graha Grafindo.

Sukirno, S. (2006). Pengantar Teori Makro. Jakarta: PT. Graha Grafindo.

Swastha, B. dan I. S. (2000). Pengantar Bisnis Modern. Yogyakarta: Liberty.

Undang-Undang No. 20 Tahun 2003. (n.d.). Sistem Pendidikan Nasional.

Widarjono, A. (2013). Ekonometrika. Yogyakarta: Edisi Keempat. 